\title{
Outsourcing or Giving All Out? Experience from Tanzania Local Government Revenue Collection
}

\author{
Mrutu Lukio (Corresponding author) \\ Assistant Lecturer, Human Resources and Public Services Management \\ School of Public Administration and Management, Mzumbe University \\ United Republic of Tanzania \\ Email:1mrutu@mzumbe.ac.tz
}

\author{
Pendo Mganga \\ Assistant Lecturer, Procurement Department \\ Jordan University, United Republic of Tanzania
}

Received: December 09, 2015 Accepted: May 26, 2016 Published: September 08, 2016

doi:10.5296/jpag.v6i3.8695 URL: http://dx.doi.org/10.5296/jpag.v6i3.8695

\begin{abstract}
Outsourcing revenue collection in Local Government Authorities has been adopted as a mechanism to solve the previous problems of revenue collection which resulted into loss and mismanagement of the whole process. One of the expectations was to increase revenue collection which will provide a room for fiscal autonomy. However, experience from few local government authorities which have outsourced their revenue collection shows that, the whole process of outsourcing has not yielded the expected outcome especially on enabling local authorities to have fiscal autonomy instead it has turned to benefit the private agent who collect Tax. By using secondary data this paper attempts to show how the process of outsourcing is benefiting the private agent and therefore it is like giving everything out. It concludes that, though outsourcing seems to benefit local authorities by reducing some tasks especially on tax collection, outsourcing benefits much a private agent and therefore quick measures should be adopted including building the capacity of Local Authorities in identifying the sources of revenue and in estimating the actual collections so as to have clear picture of how much will be generated by the agent and what should be the appropriate amount to be submitted to the Local authority.
\end{abstract}

Keywords: Revenue collection, Outsourcing, Local Government Authorities 


\section{Introduction}

One of the remaining challenges to many developing countries in the world is financial crisis. Inability to support their own development initiatives is mentioned as the reason towards the adoption of fiscal decentralization whereby central governments are trying to reduce their role in managing development and to rely more on local governments (Smoke, 2001). Many developing countries face a number of deficiencies when it comes to revenue collection through tax whereby majority of people are poor to the extent that they cannot pay tax and those who are political and financial powerful they do not want to pay tax (O. H. Fjeldstad \& Rakner, 2003). As a curbing mechanism to tax evasion and inefficiency in tax collection, giving local authorities a certain level of autonomy in fiscal realm is thought as panacea. Fiscal decentralization, which refers to the devolution of taxing and spending powers to lower levels of government to facilitate their financial capacity, has become an important theme of governance in many developing countries in recent years (Fjeldstad and Semboja, 2000). Through fiscal decentralization, local authorities identify different sources of revenue, manage them and collect substantial revenue that will enable them to finance their own development activities.

However, despite the introduction of fiscal decentralization, evidence shows that many local authorities fail to implement their development projects and meet the service needs of the people because of the shortage funds (Dollery, Crase, \& Grant, 2011). Inability to identify new sources of revenue, failure to utilize the available sources caused by the lack of capacity (mechanisms and skilled personnel) to collect enough revenue, is mentioned as the paramount reason for financial crisis to many local authorities in the world (Opoku, Kyeremeh, \& Odoom, 2014). Because of financial crisis, many Local authorities have been lagging behind in ensuring sufficient revenue collection something, which have rendered them powerless and recipient of funds from central government.

To alleviate the weakness in revenue collection, the use of an agent (private sector) in the name of outsourcing to collect revenue has gained popularity in recent years to many Local governments in the world. Outsourcing in local government authorities, which came as the result of management reforms in public sectors organizations through New Public Management (NPM) and New Public Financial Management (NPFM) practices introduced in revenue collection to help local authorities collect enough revenue for their own use (Hood \& Lodge, 2004; Olson, Guthrie, \& Humphrey, 1998).

One of the challenges facing decentralization reforms in Tanzania is to identify new sources of revenue and have effective mechanisms to ensure sufficient revenue collection (B. O. Fjeldstad, Katera, \& Ngalewa, 2005). As a result, many local government authorities have been experiencing insufficient revenue and therefore fails to finance the provision of social services to the people (Siasa \& Mzenzi, 2004). To address the challenge of insufficient revenue, which mostly caused by inability to identify new sources of revenue, tax evasion and increasingly tax administrative costs, several initiatives have been taking place including rationalization in 2003 whereby some of the taxes including development levy were abolished. To facilitate efficiency in revenue collection, some local council has decided to 
outsource their revenue collection to a private agent. For example, up to September 2003 in Bagamoyo District Council Forest levy, Bus stand fee, Sand mines levy, Hotel levy and Murram and aggregates tax sources were outsourced to private agents (Fjeldstad, Henjewele, Mwambe, Ngalewa \& Nygaard, 2003).

However, despite the good motives of adopting outsourcing in revenue collection by local councils, local councils have not yet managed to have enough funds to finance their activities. Reports shows that the outsourced sources of revenue have benefited more the private agent that the local authorities contrary to the expectations (B. O. Fjeldstad et al., 2005). This paper aims at showing how the outsourcing in revenue collection has turned to be a blessing to a private agent and a pain to local authorities.

The paper starts by elucidating aspects of fiscal decentralization, outsourcing and outsourcing in revenue collection. It goes further by describing the status of revenue collection in Tanzania local government authorities. To examine how outsourcing in revenue collection has turned to be a blessing to private agent, this paper uses the reports of Fjeldstad, Katera \& Ngalewa (2005), and the Controller Auditor General of 2014. To make

\section{Fiscal Decentralization}

From early 1990s, many developing countries opted for fiscal decentralization embedded in local government reforms with the motives of facilitating local development through effective and efficient management of local resources (World Bank, 2000). However, there have been some arguments as whether fiscal decentralization will be a panacea or an additional burden to existing problems in developing countries. Under this dilemma, some argue for decentralization as it facilitate efficiency, some on the grounds of improved accountability and others on the grounds of resources mobilization (Bird and Vaillancourt, 2008). On the other hands, some argue against fiscal decentralization on the grounds of low capacity of local authorities to fully manage and utilize available resources and therefore decentralization under this trajectory is viewed as a tool towards costs increase, inefficiency and inequity (Prud'homme, 1995). More interesting the debate on whether decentralization worthy for developing countries or not, has left many puzzle to many scholars, economist, policy analyst and politicians all over the world due to the fact little has been achieved as compared to projected benefits. It has been from this perspective where Bird and Vaillancourt, 2008 argues that economist are theorising fiscal decentralization, applied economist are busy measuring the effects of decentralization while policy economist are busy flying around the world giving advice about decentralization.

\section{The Emerging of Outsourcing}

Outsourcing, which refers to the process of contracting out the services or activities which were previously done by internal staff to the private agent, is becoming so popular in many parts of the world under the notion of increasing efficiency and effectiveness in service delivery (Walker et al, 2006). The recent and ongoing transformation in Public administration under New Public Management in the early of 1970s and 198s can be viewed as the source of adoption of outsourcing in service delivery to many public organizations (Gruening, 2001). 
One of the key elements of New Public Management is to facilitate efficiency in service delivery with focus on cost reduction while maintain the high standards of service quality and customer satisfaction under defined measures of performance.(Gupta, Herath \& Mikouzai, 2005; Hemphill, 2004; Lacity, Willcocks \& Feeny, 2004 cited in Walker et al, 2006). It is obvious that the adoption and embarrassment of outsourcing practices have been associated with the need to meet the demands of people at all levels in timely, quantity and quality basis while reducing the costs and risks sharing.

\section{The Theories of Outsourcing}

Outsourcing is a complex process, which involves a number of activities, which all together leave some dilemmas. In this juncture, several theories have been developed to facilitate the understanding of the process and its practices (Jørgen and Pedersen, 2007). As a process, outsourcing takes place in five phases from preparation, vendor(s) selection, transition, transition, managing relationship and reconsideration. In all these phase key questions have been asked and answered to determine whether outsourcing is panacea, what should be outsourced, to whom, how and when etc (Jørgen and Pedersen, 2007). Based on these, there are so many theories, however in this paper, the most used theories as identified by Jorgen and Pedersen are discussed hereunder.

\subsection{Transaction Cost Theory (TCT)}

The early ideas of this theory came from Nobel Laurete R. Coase and later developed by O.E.Williamson. This theory has been widely used to determine the decision as whether the organization has to outsource or not (Ellram et al, 2008; Tate et al., 2008, 2009). The major assumption in this theory is that, firms decision to outsource is largely influenced by economic reasons (Williamson,1975, 2007). Under this theory, three major transaction costs variables are described which involves asset specificity, uncertainty and transaction frequency. In this case, any decision towards outsourcing has to consider those variables whereby in asset specificity things like machinery or tools, human assets including their skills and knowledge, site location and natural resources available is very important (Williamson, 1975). In addition, uncertainty as far as the environment and behavior of the practitioners is dynamic and lastly how many number of transactions will be involved (Williamson, 1985).

\subsection{Resource-based View}

The foundation of this theory is the logic that each organization is made up with different productive resources which differ from one organization to another (Neves, Hamacher, \& Scavarda, 2013). In this case, each organization tries to build its competitive advantage by properly organizing and utilizing whatever resources it has, to survive in business environment. In outsourcing, resource based view theory provides that, organizations which lacks or which are weak in some kind of resources and capabilities will decide to look for external provider to fill the gap (Jørgen and Pedersen, 2007). Generally, resource based theory is mostly used in making key decisions whether to outsource or not and also to decide the type of vendor to be employed (Roy \& Aubert, 2001). 


\subsection{Concept of Core Competences}

Each organization has its own kind of activities, which makes it unique from other organizations. In this case, a question has been what kind of activities an organization should remain with and what kind of activities has to outsource (Nellore \& Söderquist, 2000). Many scholars are of the opinion that, organization core activities should not be outsourced so as to keep its competitive advantage $(\mathrm{Xu}, 2009)$. It is also argued that organization's decision to outsource should also be accompanied with proper selection of vendors whereby the competencies of vendors influence the success of outsourcing (Levina \& Ross, 2003)

\section{Outsourcing Revenue Collection}

Outsourcing revenue collection has been a common practice in many today's governments. Sometimes known as tax farming, has been accepted world wide as an alternative mechanism of revenue collection with the principal notion of increasing efficiency and effectiveness. It refers to the process whereby the right to collect tax is shifted from the government to a private agent herein referred as a highest bidder (Stella, 1993). The use of private agents in tax collection is not new because it has been practiced in different forms during ancient times in Egypt, India and Mesopotamia to mention few (ca. 1750 B.C. in Stella, 1983). Tax collection through the use of private agents was is identified as one of the important mechanism which helped Prussia to collect sufficient revenue during (Schneider \& Kiser, 2015).

Though tax collection practices through contractual arrangements is not new, there has been an endless debate as to whether the government should collects its own taxes through a private agent or having internal arrangements for collection. Those who emphasis on tax collection through a private agent argues that, using a private agent in tax collection reduce administrative costs to the government and therefore create enough space for the government to engage in other important activities (Stella, 1993). In addition, there is another claimed justification for tax farming, that is, it leads to maximization of revenue collected. It is believed that, giving a private agent the rights to collect tax, which is described as a social inefficient entity (Stella, 1993) that seek to maximize profit will enable the increase in tax collection especially in those considered as a problematic taxes in collection (B. O. Fjeldstad et al., 2005). Despite the colorful and probably the most beautiful justifications, tax farming is most expensive practice as it is only the shifting (sometimes replicating) of administrative costs from the government to a private agent. For example, Collins (1988) shows that the tax collectors in France had to employ at least 75000 people as tax collectors and according to him these were the costs incurred by tax collectors. In this case, outsourcing revenue collection might results into huge collections but the net revenue to be enjoyed by the principal is little as the agent will deduct much as administrative costs. Stella (1993) argues the focus on increasing revenue collection and reduction of administrative costs has long-term effects including the increase of social unrest especially when tax collection mechanism by the agent will ignore the democratic features of protecting and safeguarding human rights. In Dutch republican social unrests were vivid as a result of harsh treatments to taxpayers by tax collectors (De Vries, 1976). 


\section{Tax Collection in Tanzania}

Revenue through taxing remain the most depended revenue all governments of the world both rich and poor ones (Apronius \& Mbilinyi, 2002). In this case, the process of tax collection and its outputs need to be careful monitored and regulated to ensure the collection of enough revenue as projected (Stella, 1993). However, many developing countries including Tanzania, effectiveness and efficiency in generating enough revenue through taxing remains a living myth. Tanzania known by its political stability since its political independence of 1961 with many natural resources, has remained as an aid recipient due to its weaknesses in tax collection. For example tax-to GDP ratio in 2000 was around $10 \%$ compared to aid which presents almost $20 \%$ of its GDP (O. H. Fjeldstad \& Rakner, 2003).

Inheriting its tax structure from Britain (the then colonial master) which functioned until 1980s, Tanzania went through several tax reforms geared towards stabilizing country's financial capacity. However, is not the purpose of this paper to revisit all tax reforms started since 1960s, major reforms date from 1970s. There were the introduction of a progressive income tax in 1973, the repealing of the 1969 Sales Tax Act, replacing it with a new Sales Tax Act of 1976, raising import duty rates and abolition of excise duty in the late 1970s (Osoro, 1995 pg13). Other tax reforms, came a response of severe economic crisis in 1980s were to encouraging exportation through abolition of export taxes in 1985, the amendment of Sales Tax Act of 1976, the reduction of import duty was also effected in 1985 and the reintroduction of excise duty in 1989 (Osoro, 1995). These and many other reforms that came later in 1990s and those in 2000s helped to some extent to improved revenue situation for example the percentage of GDP increased from $11.8 \%$ in $2004 / 05$ to $17.9 \%$ in $2008 / 09$ (Frimpong-Ansah, 1989). The increase in revenue collection has been improving from Tsh 4,049.1 Billion in 2008/2009 to Tsh 7,739.3 Billion in 2012/2013 (The Citizen Saturday, November 16, 2013).

\section{Revenue Collection in Tanzania LGAs}

One of the characteristics of tax structures in many local authorities in developing countries is to have huge number of revenue instruments. In Tanzania for example it was very likely to find within a district there are more than 50 different taxes and fees $(\mathrm{O}$. H. Fjeldstad \& Rakner, 2003).

As a matter of fact prior to local tax reforms during 2003/2004 and 2004/2005 financial year, each local authority had its own tax arrangements something which created confusion and the increase of administrative costs which were directly transferred to taxpayers (Siasa \& Mzenzi, 2004). In 2003, there were some major tax reforms introduced by the Ministry of Finance that led to the abolishment of number of local taxes including development levy, some licenses fees, and livestock cess. Despite these reforms, local tax collection has been shadowed with a countless challenges including tax evasion, corruption and political interference. One of the arguments against tax evasion among local taxpayers has been the failure to see tangible results of the taxes they are paying (O.-H. Fjeldstad, 2001). All these have led the decrease in the amount of tax collected by local authorities leaving local authorities to rely on grants from central government (B. O. Fjeldstad et al., 2005). 


\section{Outsourcing Revenue Collection in Tanzania LGAs}

Following the failure of local authorities in collecting enough revenue through taxing, the need to use private agent has gained an important position. It is believed that the use of private agent in revenue collection increase efficiency and effectiveness and hence more revenue will be realized (Cindy, 2012). As a results since 1996 many local authorities opted for outsourcing in revenue collection by employing a private agent as tax collectors (B. O. Fjeldstad et al., 2005). Since 2000 different forms of taxes like property tax, market fees, forest levies in many local authorities were outsourced to private agent (B. O. Fjeldstad et al., 2005). The current outsourcing arrangements are characterized by open, competitive tendering process guided by the Local Government Reform Program (June 2003) and the Public Procurement Act No 21 of 2004. Under these arrangements competent bidders are invited to express their interest and through the tendering board in each local authorities one bidder is chosen based on prescribe criteria by the Public Procurement Act of 2004 (B. O. Fjeldstad et al., 2005).

\section{Empirical Evidence from Outsourced Revenue Collection}

This part provides experience from outsourced revenue collection by review a report by B. O. Fjeldstad et al., 2005 and Controller Auditor General Report. The purpose is to unveil the real practices of outsourcing revenue collection. A study by B. O. Fjeldstad et al., 2005 titled Outsourcing Revenue Collection: Experiences from Local Government Authorities in Tanzania will be reviewed together with CAG report of 2014. A study by B. O. Fjeldstad et al., 2005 which studded three different cases, that is, Dar es Salaam City Council, Mwanza City Council and Moshi District Council shows that there are leakages which abstain Local Authorities benefiting from outsourced revenue.

\subsection{Dar es Salaam City Council}

In Dar es Salaam City Council the major sources of revenue outsourced includes fees for vehicles and passengers entering Ubungo Bus Terminal together with parking fees around city centre. The collection of fees at Ubungo Bus Terminal was outsourced since 1996 and for the parking fees was outsourced in 1999. From the estimation of 2002 by the city council, the projection was 3.1 Million Tsh. In this case, from the contract arrangements, the agent was supposed to remit a sum of 1.5 Million per day i.e. 52 percent of the collected revenue. REPOA independent team of researchers conducted a simple study from 16-23 August 2006 to determine the actual amount of money collected on daily basis by counting the number of vehicles entering and parking in the terminal revealed that there was an average of 3, 397,014 Tsh. Collected daily at the terminal. In this case, the city council receives only $44 \%$ of the revenue and the rest 56\% retained by the agent (B. O. Fjeldstad et al., 2005).

\subsection{Mwanza City Council}

Mwanza City Council is also one of the local authorities, which outsourced its revenue collection. The revenue collection from Mwaloni fish market and Central market were outsourced to different bidders following a survey conducted by the city to identify revenue potential. Initially the two markets outsourced resulted into substantial collections surpassing 
the previous collected amount by the city council. Other outsourced revenue collection from 1997 did not result into good returns due to poor assessment of revenue potential and political interference during tendering process. As a result the city lost a lot of revenue whereby more revenue were retained by agents (B. O. Fjeldstad et al., 2005).

\subsection{Moshi District Council}

The collections from coffee contribute $28 \%$ of total tax revenue from agricultural products in Moshi District Council in 2005/2006. All these taxes are collected by Kilimanjaro Native Cooperative Union and have to be paid in four installments to the council. However, the union has not been effective and most of the time fails to remit the agreed amount to the council. One of the identified weakness, which results into loss of millions of money, is the failure by the council to verify whether the amount collected and submitted by the union reflect the real collections. (B. O. Fjeldstad et al., 2005)

\section{Controller Auditor General Reports}

From CAG reports Local Authorities do not benefit much from outsourced revenue sources instead it is collecting agents who enjoy the returns. Due to weak administrative capacity, many local authorities have failed to assess potential sources of revenue and to have effective mechanisms to ensure the agreed amount between them and the agent is remitted. According to CAG report of 2014 almost 54 Local Government Authorities had uncollected revenue from agents worthy TShs 4, 843, 414, 724 as of 30 June 2014. The same trend happened for the past three years where in 2012/2013 a total of 6, 710, 548, 469 TShs was unremitted, in 2011/2012 a total of 4, 466,028, 478 TSh was unremitted and a total of 4, 360, 299, 618 TShs was unremitted (PMO-RALG, 2013).

\section{Discussion}

Though outsourcing revenue collection has somewhat led to the increased amount of revenue collected by local authorities, yet the intended goal has not yet been realized. Through outsourcing revenue collection in local councils, there has been some improvements to the extent of facilitating local budgeting process. For example while some Councils' in the financial year 2009/10 managed to finance only $7.5 \%$ of their total recurrent expenditures, local revenues of some of the urban Councils such as Temeke, Ilala, Kinondoni, and Arusha Municipal Councils, individually, were able to finance their recurrent expenditures by more than 20\% (CAG, 2011 cited in Siasa, 2004 pg 10). Despite these increase in some figures due to outsourcing arrangements, empirical evidence shows that, outsourcing benefits private agents than Local authorities. Empirical evidence from Dar es Salaam city council, Mwanza city Council and Moshi District Council shows that outsourcing revenue collection has ended up benefiting private agents. Failure to assess revenue potentials and weak monitoring process has resulted into substantial loss of revenue (B. O. Fjeldstad et al., 2005). Losing more than $50 \%$ of the collected revenue to an agent is a huge loss considering the financial situation of many Local Authorities in Tanzania. Outsourcing revenue collection is undoubtedly a public private partnership mechanism which not only intended to reduce tax collection burden to Local Government Authorities and subsequently increase the amount of 
revenue collected, has turned to be a loophole for private agent to reap huge profit. As Stella 1993 argued, the justification that outsourcing will reduce administrative costs and increase revenue capacity has no evidence especially in developing countries because the same costs that the government had to incur are to be borne by the private agent and therefore deducted from net government revenue.

\section{Conclusion}

The acceptance and practice of outsourcing as a new strategy for revenue collection in many developing countries and more specifically in Tanzania Local Government Authorities has proved to be demonic tool to benefit private agents. The financial capacity of these Local councils has been weakening each year, and hence relying more on grants, donation and support from central government. It cannot be a sin to conclude that the adoption of this practice was stirred by political influences with little or no economic rationalities. Because one of the identified reasons for such poor performance of outsourced sources has been the weak administrative capacity to assess the potential sources of revenue and make rational projection that will help in curbing revenue collectors to bring required revenue. From this juncture, outsourcing in revenue collection in Tanzania Local Authorities has turned to be a "giving all" practice which not only results into weak financial base but also negatively affect the provision of public services at the required rates.

\section{References}

Apronius, B., \& Mbilinyi, V. (2002). POLICY BRIEF No : 5 CURBING TAX EVASION BY PROFESSIONAL SERVICE, 1-16.

Bird, R., \& Vaillancourt, F. (2008). Fiscal decentralization in developing countries. Retrieved from

http://books.google.com/books?hl=en\&lr=\&id=_wraZ5HEMasC\&oi=fnd\&pg=PP1\&dq=Fisc al+Decentralization+in+Developing+Countries+edited+by\&ots=relfqjJRdQ\&sig=AIGNPl3U nqKf873MKAImxsCGHRg

Cindy, Y. Z. (2012). Managing risks in offshore outsourcing relationships with China: a relational view By.

Conference, A. (2007). Outsourcing Process and Theories.

Dollery, B., Crase, L., \& Grant, B. (2011). The Local Capacity , Local Community and Local Governance Dimensions of Sustainability in Australian Local Government, (2005).

europe economy.pdf. (n.d.).

Fjeldstad, B. O., Katera, L., \& Ngalewa, E. (2005). Outsourcing Revenue Collection: Experiences from Local Government Authorities in Tanzania. Public Administration, (until).

Fjeldstad, O. H., \& Rakner, L. (2003). Taxation and tax reforms in developing countries: Illustrations from sub-Saharan Africa. Report - Chr. Michelsen Institute. 


\section{I Macrothink}

Journal of Public Administration and Governance ISSN 2161-7104 2016, Vol. 6, No. 3

Fjeldstad, O.-H. (2001). Taxation, Coercion and Donors: Local Government Tax Enforcement in Tanzania. The Journal of Modern African Studies, 39(2), 289-306. http://doi.org/10.1017/S0022278X01003627

Fjeldstad, O.-H., \& Semboja, J. (2000). Dilemmas of Fiscal Decentralisation: A Study of Local Government Taxation in Tanzania. Forum for Development Studies, 27(1), 7-41. http://doi.org/10.1080/08039410.2000.9666122

Frimpong-Ansah, J. (1989). Domestic resource mobilization in Africa. Retrieved from http://www.getcited.org/pub/100090299

Government, L. (2013). THE UNITED REPUBLIC OF TANZANIA PRIME MINISTER' S OFFICE , Final Report A Study on LGAs Own Source Revenue Collection.

Gruening, G. (2001). Origin and theoretical basis of new public management. International Public Management Journal, 4(1), 1-25. http://doi.org/10.1016/S1096-7494(01)00041-1

Nellore, R., \& Söderquist, K. (2000). Strategic outsourcing through specifications. Omega, 28(5), 525-540. http://doi.org/10.1016/S0305-0483(99)00078-X

Neves, L. W. D. A., Hamacher, S., \& Scavarda, L. F. (2013). Outsourcing from the perspectives of TCE and RBV: a multiple case study. Produção, 24(3), 687-699. http://doi.org/10.1590/S0103-65132013005000082

Opoku, E., Kyeremeh, C., \& Odoom, D. (2014). Local Revenue Mobilization Mechanisms : Evidence from the Abura-Asebu-Kwamankese District in Ghana, 4(26), 125-138.

Osoro, N. E. (1995). Tax reforms in Tanzania: Motivations, Directions and Implications.

Roy, V., \& Aubert, B. (2001). A Resource-Based Analysis of Outsourcing: Evidence from Case Studies.

Schneider, J. (2015). American Sociological Review, 59(2), 187-204.

Siasa, B., \& Mzenzi, I. (2004). POLICY BRIEF No : 7 Revenue Mobilization Issues in the Tanzanian LGAs, (7).

Smoke, P. (2001). Fiscal Decentralization in Developing Countries A Review of Current Concepts and Practice, (2), 51. http://doi.org/10.1353/jda.2004.0001

Utsourcing, O., \& Ross, J. W. (2003). R ESEARCH A RTICLE F ROM THE V ENDOR ' S P ERSPECTIVE: E XPLORING THE V ALUE P ROPOSITION IN I NFORMATION T ECHNOLOGY, 27(3), 331-364.

Walker, H. (2006). Outsourced Services and “ Imbalanced” Supply Markets, 24(1), 95-105. http://doi.org/10.1016/j.emj.2005.12.011

Williamson, O. E. (2007). Transaction Cost Economics: An Introduction. Economics Discussion Paper, 0-33.

Xu, Y. (2009). Master Programme in Economic Growth , Innovation and Spatial Dynamics 


\section{Macrothink}

Journal of Public Administration and Governance ISSN 2161-7104 2016, Vol. 6, No. 3

Determinants of Outsourcing Transaction Cost Economics and Core Competencies Theory Determinants of Outsourcing: Transaction Cost Economics and Core Competencies Theory Contents.

Zoran, P. and Pedersen J.P ( 2007). Outsourcing Process and Theories, POMS 18th Annual Conference, Dallas, Texas, U.S.A.

The Citizen Saturday, November 16, 2013, http://www.thecitizen.co.tz/Business/Bilal-urges-TRA-to-address-tax-evasion-and-avoidance/ -/1840414/2075328/-/oxujbk/-/index.html

\section{Copyright Disclaimer}

Copyright for this article is retained by the author(s), with first publication rights granted to the journal.

This is an open-access article distributed under the terms and conditions of the Creative Commons Attribution license (http://creativecommons.org/licenses/by/3.0/). 